\title{
PERAN PEMERINTAH DAERAH DALAM PEMBERDAYAAN PEREMPUAN DI KELURAHAN KALEGOWA, KECAMATAN SOMBA OPU KABUPATEN GOWA
}

\author{
Adzimad Tinur Haque ${ }^{1}$, Budi Setiawati ${ }^{2}$, Nuryanti Mustari ${ }^{1}$ \\ 1Program Studi Ilmu Pemerintahan Fakultas Ilmu Sosial dan Ilmu Politik \\ Universitas Muhammadiyah Makassar \\ Jl Sultan Alauddin No 259 Makassar 90221 \\ Telp. 0411-866972 ext. 107. Fax. 0411-8655888 \\ adzimad tinur@yahoo.com nuryantim@yahoo.co.id \\ 2 Program Studi Ilmu Adminitrasi Negara Fakultas Ilmu Sosial dan Ilmu Politik \\ Universitas Muhammadiyah Makassar \\ Jl Sultan Alauddin No 259 Makassar 90221 \\ Telp. 0411-866972 ext. 107. Fax. 0411-8655888 \\ budi setiawati@yahoo.co.id
}

\section{ABSTRACT}

Various phenomena related to women both in the political, economic, social, cultural and existential creates differences between men and women. Who gave birth to the idea that the position of women and men differ, women tend to be subordinate in the household. Therefore, in this paper want to see the role of the Family Planning and Women's Empowerment in improving the quality of women. Peneliian uses descriptive research is data collected kualitatiff dideskriptifkan based on direct interviews and direct observation in the field. Role of the Family Planning and Women's Empowerment in Women's Empowerment is to socialize the business group to participants empowerment, mentoring ranging from the preparation, implementation and evaluation, and the latter is training, which includes the training of making traditional snacks, training party bag and training dressmaking, in the event that serves as the implementing agency ie Family Planning and women's empowerment assisted by NGOs (Non Governmental Organization) as well as the PKK, while functioning as a participant that will empower women. With the passage of the role women can already malakukan Access, Control, Benefits and Participation.

Keywords: BKBPP, Women's Empowerment, Community

\begin{abstract}
ABSTRAK
Berbagai fenomena terkait dengan perempuan baik dalam bidang politik, ekonomi, sosial, dan budaya menciptakan perbedaan eksistensial antara laki-laki dan perempuan. Hingga melahirkan pemikiran bahwa kedudukan perempuan dan laki-laki berbeda, perempuan cenderung sebagai subordinat dalam rumah tangga. Untuk itu, dalam tulisan ini hendak melihat peran Badan Keluarga Berencana dan Pemberdayaan Perempuan dalam meningkatkan kualitas perempuan. Peneliian ini menggunakan penelitian deskriptif kualitatiff yaitu data yang dikumpulkan dideskriptifkan berdasarkan hasil wawancara langsung dan pengamatan langsung di lapangan. Peran Badan Keluarga Berencana Dan Pemberdayaan Perempuan dalam Pemberdayaan Perempuan yaitu dengan melakukan sosialisasi tentang kelompok usaha kepada peserta pemberdayaan, pendampingan mulai dari tahap persiapan, pelaksanaan hingga evaluasi, dan yang terakhir yaitu pelatihan yang didalamnya berisi pelatihan pembuatan jajanan pasar, pelatihan tas pesta dan pelatihan penjahitan, dalam kegiatan tersebut yang berfungsi sebagai pelaksana yaitu Badan Keluarga Berencana Dan Pemberdayaan Perempuan yang dibantu oleh LSM ( Lembaga Swadaya Masyarakat) serta tim penggerak PKK, sedangkan yang berfungsi sebagai peserta yaitu perempuan yang akan melakukan pemberdayaan. Dengan berjalannya peran tersebut perempuan sudah bisa malakukan Akses, Kontrol, Manfaat dan Partisipasi.
\end{abstract}

Kata Kunci : BKBPP, Pemberdayaan Perempuan, Masyarakat 


\section{A. LATAR BELAKANG}

Hadirnya berbagai fenomena yang terkait dengan perempuan baik dalam bidang politik, ekonomi, sosial, dan budaya saat ini seakan-akan sebagai bentuk rekognisi perempuan terhadap kualitas mereka. Dimana selama ini stigma mengenai kedudukan perempuan dan laki-laki berbeda, perempuan hanya sekedar ibu rumah tangga yang mendampingi laki-laki sebagai kepala rumah tangga, tugas perempuan hanya mengurusi suami dan anak sedang laki-laki bertugas menafkahi keluarganya.

Adanya modernisasi kehidupan, maka pemikiran tersebut mulai berubah, perempuan juga mampu mendapat pengakuan yang sama dengan laki-laki, dalam artian perempuan mampu menambah penghasilan finansial keluarga dimana sebelumnya laki-laki (suami) yang bertindak sebagai pencari nafkah.

Perempuan sejak dahulu telah aktif dalam kegiatan ekonomi dan sosial sebagai petani, pedagang, pekerja (di sektor informal), dan sebagai ibu rumah tangga. Namun, kebanyakan perempuan belum menikmati penghargaan dan penghormatan yang sama dengan lakilaki sesuai sumbangan dan beban kerjanya sebagai dampak diskriminasi perempuan yang terus terjadi. Sehingga diseluruh dunia, sebagaian besar dari mereka yang miskin terdiri dari, perempuan yang hingga kini masih dirugikan, berbagai kelompok masyarakat, termasuk LSM, telah memainkan peran penting yakni memobilisasikan anggapan umum tentang isu-isu penting terkait perempuan dengan tujuan akhir memberdayakan perempuan.

Cara pandang perempuan untuk memenuhi kebutuhan hidupnya tidak dianggap sebagai pekerjaan yang di nilai secara ekonomi. Produksi makanan keluarga, memelihara dan mendidik anak, memelihara kesehatan keluarga, melakukan penghematan dan pengeluaran dan pekerjaan rumah tangga lainnya yang dianggap bukan kegiatan produktif dan tidak mempunyai nilai ekonomi. Padahal realitas hidup menunjukkan, kaum perempuan selalu menghidupi keluarganya ketika suami sebagai kepala keluarga tidak memenuhi kebutuhan keluarganya.

Komitmen pemerintah untuk mempercepat pertumbuhan ekonomi kerakyatan sangat gencar dilakukan seiring dengan perkembangan perekonomian umumnya di negara kita dan khususnya di daerah kita. Oleh karena itu sangatlah besar harapan pemerintah agar kiranya apa yang diharapkan pemerintah dapat bersinergi dengan masyarakat itu sendiri. Dengan adanya kepedulian pemerintah, maka semua itu menjadi sebuah keharusan dan kewajiban perempuan sebagai pengendali ekonomi dalam rumah tangga khusunya untuk dapat berperan aktif dalam menciptakan kehidupan yang lebih mandiri dan berkreatif.

Dalam kebijakan dan strategi mengenai pembangunan dan pemberdayaan perempuan di Indonesia yang disusun pemerintah, dicantumkan tentang visi dan misi pemberdayaan perempuan. Visi pemberdayaan perempuan adalah terwujudnya kesetaraan dan keadilan gender dalam kehidupan berkeluarga, bermasyarakat dan bernegara.

Sejak reformasi, paling tidak secara yuridis, kesetaraan antara lakilaki dan perempuan semakin baik. Hal ini terlihat dari amandemen UUD Republik Indonesia pasal 27 dan 28 yang mengukukuhkan persamaan hak dan kewajiban antara perempuan dan 
laki-laki sebagai warga Indonesia. Sebelumnya, di masa Orde Baru, Indonesia meratifikasi Konvensi Penghapusan Segala Bentuk Diskriminasi Terhadap Perempuan dengan UU Nomor 7 Tahun 1984. Menurut catatan tahunan Komisi Nasional Anti Kekerasan Terhadap Perempuan (Komnas Perempuan) 2007, telah dihasilkan 29 Produk kebijakan untuk menangani dan menghapuskan kekerasan terhadap perempuan, berupa : 11 kebijakan di tingkat nasional, 15 kebijakan di tingkat daerah dan 3 kebijakan regional ASEAN. Antara lain, UU Pengadilan HAM (2000). UU Perlindungan Anak (2002), UU Penghapusan Kekerasan Dalam Rumah Tangga/KDRT (2004), UU Pemberantasan Tindak Pidana Perdagangan Orang (2006), dan UU N0. 12 Tentang Kewarganegaraan.

Pemberdayaan perempuan dan tercapainya kesetaraan jender merupakan merupakan masalah hak asasi manusia dan ketidakadilan sosial dan salah bila dipersepsikan sebagai isu perempuan saja, disinilah letak peran Badan Keluarga Berencana dan Pemberdayaan Perempuan dalam merubah kondisi sosial tersebut, karena masalah dan kondisi sosial tersebut merupakan persyaratan dan dalam proses pembangunan masyarakat yang adil dan kesejahteraan rakyat yang berkelanjutan.

Kurangnya sosialisasi dan dukungan lintas sektoral tentang pengarusutamaan gender di lingkungan masyarakat dan belum optimalnya peran pemberdayaan perempuan adalah merupakan salah satu kendala yang sedang dihadapi perempuan khususnya di Kelurahan Kalegowa, Kecamatan Somba opu, Kabupaten Gowa. Hal ini mendorong tim penulis untuk melakukan penelitian mengenai : "Peran Badan Keluarga Berencana Dan Pemberdayaan Perempuan Di
Kelurahan Kalegowa, Kecamatan Somba opu, Kabupaten Gowa.

\section{B. KONSEP PERAN PEREMPUAN}

Teori peran adalah sebuah sudut pandang dalam sosiologi dan psikologi sosial yang menganggap segagian besar aktivitas harian diperankan oleh kategori-kategori yang ditetapkan secara sosial (misalnya ibu, manajer, guru). Setiap peran sosial adalah serangkaian hak, kewajiban, harapan, norma, dan perilaku seseorang yang harus dihadapi dan dipenuhi. Model ini didasarkan pada pengamatan bahwa orang-orang bertindak dengan cara yang dapat diprediksikan, dan bahwa kelakuan seseorang bergantung pada konteksnya, berdasarkan posisi sosial dan faktor-faktor lain. Teater adalah metafora yang sering digunakan untuk mendeskripsikan teori peran.

Meski kata "peran" sudah ada di berbagai bahasa eropa selama beberapa abad, sebagai suatu konsep sosiologis, istilah ini baru muncul sekitar tahun 1920-an dan 1930-an. Istilah ini semakin menonjol dalam kajian sosiologi melalui karya teoretis Mead, Moreno, dan Linton, dua konsep Mead yaitu pikiran dan diri sendiri adalah pendahulu teori peran. Tergantung sudut pandang umum terhadap tradisi teoretis, ada serangkaian "jenis" dalam teori peran. Teori ini menempatkan persoalan persoalan berikut mengenai perilaku sosial:

1. Pembagian buruh dalam masyarakat membentuk interkasi di antara posisi khusus heterogen yang disebut peran;

2. Peran sosial mencakup bentuk perilaku "wajar" dan "dizinkan", dibantu oleh norma sosial, yang umum diketahui dank arena itu mampu menentukan harapan;

3. Peran ditempati oleh individu yang disebut "aktor"; 
4. Ketika individu menyetujui sebuah peran sosial yaitu ketika mereka menganggap peran tersebut "sah" dan "konstruktif", mereka akan memikul beban untuk menghukum siapapun yang melanggar normanorma peran;

5. Kondisi yang berubah dapat mengakibatkan suatu peran sosial dianggap kadaluarsa atau tidak sah, yang dalam hal ini tekanan sosial berkemungkinan untuk memimpin perubahan peran;

6. Antisipasi hadiah dan hukuman, serta kepuasan bertindak dengan cara prososial, menjadi sebab para agen patuh terhadap persyaratan peran.

Dalam hal perbedaan dalam teori peran, disatu sisi ada sudut pandang yang lebih fungsional, yang dapat dibedakan dengan pendekatan tingkat lebih mikro berupa tradisi interaksional simbolis. Jenis teori peran ini menyatakan bagaiman dampak tindakan individu yang saling berkaitan terhada masyarakat., serta bagaimana suatu sudut pandang teori peran dapat di uji secara empiris.

Kunci pemahaman teori ini adalam bahwa konflik peran terjadi ketika seseorang diharapkan melakukan beberapa peran sekaligus yang membawa pertentangan harapan.

Menurut Dougherty \& Pritchard (1985) dalam Bauer (2003), teori peran ini memberikan suatu kerangka knseptual dalam studi perilaku di dalam organisasi. Mereka menyatakan bahwa peran itu "melibatkan pola penciptaan produk sebagai lawan dari perilaku atau tindakan" (143). Lebih lanjut, menurut Dougherty \& Pritchard (1985) dalam Bauer (2003: 56) mengemukakan bahwa relevansi suatu peran ini akan bergantung pada penekanan peran tersebut oleh penilai dan pengamat (biasanya supervisor dan kepala sekolah) terhadap produk atau outcome yang dihasilkan. Dalam hal ini, strategi dan struktur organisasi juga terbukti mempengaruhi peran atau role perception (Kahn, et al., Oswald, Mossholder, \& Harris, 1997 dalam Bauer, 2003: 58).

Ditinjau dari perilaku organisasi, peran merupakan salah satu komponen dari system sosial organisasi, selain norma dan budaya organisai. Di sini secara umum 'peran' dapat didefinisikan sebagai "expectations about appropriate behavior in a job position (leader, subordinate)". Ada dua jenis perilaku yang diharapkan dalam suatu pekerjaan, yaitu (1) Role Perception; yaitu persepsi seseorang mengenai cara orang itu diharapkan berperilaku; atau dengan kata lain adalah pemahaman atau kesadaran mengenai pola perilaku atau fungsi yang diharapkan dari orang tersebut, dan (2) role expectation; yaitu cara orang lain menerima perilaku seseorang dalam situasi tertentu. Dengan peran yang dimainkan seseorang dalam organisasi, akan terbentuk suatu komponen penting dal hal identitas dan kemampuan orang itu untuk bekerja. Dalam hal ini, suatu organisasi harus memastikan bahwa peran-peran tersebut telah didefinisikan dengan jelas.

\section{Konsep Pemberdayaan}

Sulistiyani (2004: 7) menjelaskan bahwa secara etimologis pemberdayaan berasal dari kata dasar, "daya" yang berarti kemampuan. Bertolak dari pengertian tersebut, maka pemberdayaan dimaknai sebagai proses untuk memperoleh daya, kekuatan atau kemampuan, dan atau pemberian daya, kekuatan atau kemampuan dari pihak yang memiliki daya kepada pihak yang kurang atau belum berdaya.

Banyak pemikir dan praktisi yang belum memahami dan mungkin tidak 
meyakini bahwa konsep pemberdayaan merupakan alternatif pemecahan terhadap dilema-dilema pembangunan yang dihadapi. Mereka yang berpegang pada teori-teori pembangunan model lama juga tidak mudah untuk menyesuaikan diri dengan pandanganpandangan dan tuntutan-tuntutan keadilan. Mereka tidak nyaman terhadap konsep partisipasi dan demokrasi dalam pembangunan tidak akan merasa tenteram dengan konsep pemberdayaan ini, lebih lanjut, disadari pula adanya berbagai bias terhadap pemberdayaan masyarakat sebagai suatu paradigma baru pembangunan. Pemberdayaan masyarakat adalah sebuah konsep pembangunan ekonomi yang merangkum nilai-nilai sosial. Konsep ini mencerminkan paradigma pembangunan baru, yakni yang bersifat "people-centered, participatory, empowering, and suistinable" (Chambers dalam Kartasasmita, 1996).

Konsep ini lebih luas dari hanya semata-mata memenuhi kebutuhan dasar (basic needs) atau menyediakan mekanisme untuk mencegah proses pemiskinan lebih lanjut (safetynet), yang pemikiran belakangan ini banyak dikembangkan sebagai upaya mencari alternative terhadap konsep-konsep pertumbuhan di masa lalu. Konsep ini berkembang dari upaya banyak ahli dan praktisi untuk mencari apa yang antara lain oleh Friedmann (1992) disebut alternative development, yang menghendaki "inclusive democracy, appropriate economic growth, gender equlity and intergenerational equity.

Konsep pemberdayaan tidak mempertentangkan pertumbuhan dengan pemerataan, karena seperti dikatakan oleh Donald Brown (1995), keduanya tidak harus diasumsikan sebagai "incompatible or antithetical". Konsep ini mencoba melepaskan diri dari perangkap 'zero-sum game' dan "trade". Ia bertitik tolak dari pandangan bahwa dengan pemerataan tecipta landasan yang lebih luas untuk pertumbuhan dan akan menjamin pertumbuhan yang berkelanjutan. Oleh karena itu, seperti dikatakan oleh Kirdar dan Silk (1995). " the pattern of growth is just a important as the rate of growth". Yang dicari adalah seperti dikatakan Ranis "the right kind of growth", yakni bukan yang vertical menghasilkan "trickle down". Seperti terbukti tidak berhasil, tetapi bersifat horizontal (horizontal flows), yakni "broadly based, employment intensive, and not compartmentalized" (Ranis, 1995).

\section{Pengertian Pemberdayaan Perempuan}

Di Indonesia, secara resmi PUG diadopsi menjadi strategi pembangunan bidang pemberdayaan perempuan melalui Inpres No. 9 Tahun 2000 Tentang Pengarusutamaan Gender Dalam Pembangunan Nasional. Pada tingkatan yang lebih rendah, dasar hukum pelaksanaan PUG juga diatur dalam Keputusan Menteri Dalam Negeri No. 132 Tahun 2003 Tentang Pedoman Umum Pelaksanaan Pengarusutamaan Gender Dalam Pembangunan Di Daerah, yang kemudian diperbaharui dengan Permendagri No. 15 tahun 2008.

Sebagai sebuah strategi, idealnya implementasi PUG dilakukan di semua institusi negara, agar keadilan gender sebagai tujuan akhir PUG dapat tercapai. Sebagai lembaga legislatif, melalui tiga fungsi yang diemban, baik fungsi legislasi, fungsi anggaran, maupun fungsi pengawasan, DPR memiliki peran penting dalam implementasi PUG. Di bidang legislasi, RUU tentang keimigrasian yang baru disahkan beberapa waktu lalu, dapat dikatakan telah berperspektif gender mengingat selama ini cukup banyak perempuan Indonesia yang menikah dengan warga asing dan mengalami masalah yang berkaitan dengan izin tinggal. Beberapa RUU dalam daftar Prolegnas tahun 2011 
seperti RUU tentang Kesetaraan Gender dan RUU tentang Perlindungan Pekerja Rumah Tangga, juga dapat dijadikan sebagai sarana optimalisasi PUG dalam Pelaksanaan fungsi legislasi DPR.

Meskipun kesadaran tentang perlunya peningkatan keterlibatan perempuan secara signifikan di kalangan partai politik telah muncul, namun hal ini perlu ditegaskan kembali lewat peraturan yang lebih mengikat dan memiliki kekuatan hukum, supaya kesadaran tersebut tidak hanya menjadi retorika belaka. Langkah-langkah kongkrit yang perlu dilakukan antara lain: (1) Membuka kesempatan yang sama kepada perempuan untuk berperan secara aktif dlaam kepengurusan partai, melalui proses yang demokratis, adil dan transparan; (2) Mempromosikan program-program yang dapat menarik pemilih perempuan, merekrut serta meningkatkan kemampuan memimpin dan berpolitik kader-kader perempuan partai, mendorong kader-kader perempuan partai untuk posisi-posisi kepemimpinan dalam partai dan menominasikan calon legislatif perempuan partai untuk ikut dalam pemilu; (3) Merancang programprogram yang berpihak kepada kepentingan perempuan dan turut memperjuangkan isu-isu keperempuanan; (4) Melaksanakan affirmative action untuk mengejar ketertinggalan perempuan dalam politik dan mendongkrak kontribusi perempuan dalam politik formal.

Pengertian pemberdayaan perempuan adalah upaya perempuan untuk memperoleh akses dan kontrol terhadap sumberdaya, ekonomi, politik, sosial, budaya, agar perempuan dapat mengatur diri dan meningkatkan rasa percaya diri untuk mampu berperan dan berpatisipasi aktif dalam memecahkan masalah, sehingga mampu membangun kemampuan dan konsep diri.

Agar tercapainya kesetaraan gender, pemberdayaan perempuanlah bukan masalah krusial dari permasalahan hak asasi manusia dan ketidakadilan sosial, sehingga permasalahan ini bukan hanya menyangkut perempuan sebagai objek utama dalam pernyimpangan kondisi sosial, sejatinya pemberdayaan perempuan merupakan prasayarat pembangunan masyarakat yang adil dan sejahtera. Karena itu, perjuangkan hak asasi perempuan yang merupakan interaksi yang makin erat antara pribadi-pribadi yang berasal dari berbagai latar belakang pendidikan, profesi dan kebangsaan. Gerakan perempuan di tingkat nasional dan internasional, telah banyak didukung perserikatan bangsa-bangsa selama 50 tahun terakhir, sehingga kebutuhan untuk kemitraan yang sejajar dengan laki-laki atau kesetaraan gender telah menjadi isu sentral dalam konfrensi dunia keempat tentang perempuan di Beijing, Cina (1995).

Berbagai kelompok dalam masyarat, termasuk LSM, telah memainkan peran yang sangat penting dalam memobilisasi anggapan umum tentang isu-isu penting tentang perempuan, dengan tujuan akhir memberdayakan perempuan. Sudah sejak lama dikenal kelompok-kelompok seperti Solidaritas Perempuan, Asosiasi Perempuan Untuk Keadilan dan Demokrasi, Suara Ibu Peduli dan akhirakhir ini Koalisi Perempuan yang semaunya secara vocal dan giat membuat program-program untuk memberdayakan perempuan.

Selain itu partisipasi perempuan dalam pembuatan keputusan publik lebih terjamin dengan lahirnya UU No. 10 Tahun 2008 Tentang Pemilihan Umum yang menjadi landasan hukum pemilu 2009. Pasal 53 UU No. 10 tahun 
2008 memuat kuota 30\% calon legeslasi perempuan, ditambah lagi dengan pasal 55 ayat 2 mencantumkan system zipper atau disetiap tiga orang bakal calon terdapat sekurang-kurangnya satu orang perempuan. Walau kemudian system ini kandas oleh putusan Mahkamah Agung, namun persentase jumlah anggota DPR perempuan hasil pemilu 2009 mengalami peningkatan, yaitu berjumlah $18,03 \%$ daripada periode sebelumnya yaitu $8,8 \%$. Adapun tujuan Pemberdayaan Perempuan adalah;

1. Meningkatkan kedudukan dan peran perempuan diberbagai bidang kehidupan berkeluarga, bermasyarakat, berbangsa dan bernegara.

2. Meningkatkan peranan perempuan sebagai pengambil keputusan dalam mewujudkan kesetaraan dan keadilan gender.

3. Meningkatkan peran kemandirian organisasi perempuan dengan mempertahankan nilai persatuan dan kesatuan.

4. Meningkatkan komitmen dan kemampuan semua lembaga yang memperjuangkan kesetaraan dan keadilan gender.

5. Mengembangkan pemberdayaan

usaha kesejahteraan keluarga dan masyarakat serta perlindungan anak.

Dalam konteks pemberdayaan perempuan, menurut Nursahbani Katjasungkan dalam diskusi Tim Perumus Strategi Pembangunan Nasional (Nugroho, 2008) mengemukakan, ada empat indikator pemberdayaan :

1. Akses, dalam arti kesamaan hak dalam mengakses sumberdayasumberdaya produktif di dalam lingkungan;
2. Partisipasi, yaitu keikutsertaan dalam mendayagunakan aset atau sumberdaya yang terbatas tersebut;

3. Kontrol, yaitu bahwa laki-laki dan perempuan mempunyai kesempatan yang sama untuk melakukan kontrol atas pemanfaatan sumberdayasumberdaya tersebut;

4. Manfaat, yaitu bahwa laki-laki dan perempuan harus menikmati hasil pemanfaatan sumberdaya atau pembangunan secara bersama dan setara.

Sumodiningrat dalam Nugroho (2008) menjelaskan untuk melakukan pemberdayaan perlu tiga langkah yang berkesinambungan yang menjadi pokok peran pemberdaayaan perempuan yakni:

1. Pemihakan, artinya sebagai pihak yang diberdayakan harus dipihaki daripada laki-laki;

2. Penyiapan, artinya pemberdayaan menuntut kemampuan perempuan untuk bisa ikut mengakses, berpartisipasi, mengontrol, dan mengambil manfaat;

3. Perlindungan, artinya memberikan proteksi sampai dapat di lepas.

\section{METODE PENELITIAN}

Dalam penelitian ini menggunakan jenis penelitian deskriptif kualitatif yakni penelitian tentang data yang dikumpulkan dan dinyatakan dalam bentuk kalimat, misalnya kalimat hasil wawancara antara peneliti dan informan. Selain itu penelitian inipun menggunakan teknik Grounded research adalah suatu metode penelitian yang mendasari diri kepada fakta dan menggunakan analisa perbandingan bertujuan untuk mengadakan generalisasi empiris, menetapkan konsep-konsep, membuktikan teori dan mengembangkan teori dimana pengumpulan data dan analisa data berjalan pada waktu yang bersamaan. 
Menurut Nasution data primer adalah data yang dapat diperoleh langsung dari lapangan atau tempat penelitian. Kata-kata dan tindakan merupakan sumber data yang diperoleh dari lapangan dengan mengamati atau mewawancarai. Data sekunder adalah data yang didapat dari sumber bacaan dan berbagai macam sumber lainnya yang terdiri dari surat-surat pribadi, buku harian, notulen rapat perkumpulan, sampai dokumendokumen resmi dari berbagai organisasi, lampiran-lampiran dari badan resmi seperti kementeriankementerian, hasil-hasil studi, tesis, hasil survey, studi histori, dan sebagainya.

Informan pada penelitian ini berjumlah delapan orang. Pengumpulan data merupakan langkah yang sangat penting dalam penelitian, karena itu seorang peneliti harus terampil dalam mengumpulkan data dan agar mendapatkan data yang valid. Prngumpulan data adalah prosedur yang sistematis dan standar untuk memperoleh data yang diperlukan. Obeservasi langsung adalah cara pengambilan data dengan mata tanpa ada pertolongan alat standar lain untuk keperluan tersebut. Wawancara adalah proses memperoleh keterangan untuk tujan penelitian dengan cara Tanya jawab, sambil bertatap muka antara si penanya dengan si pnejawab dengan menggunakan alat yang dinamakan interview guide (panduan wawancara).

Adapun waktu penelitian dimulai dari awal bulan februari hingga awal bulan april, adapun lokasi penelitian bertempat di Kelurahan Kalegowa, Kecamatan Somba Opu, Kabupaten Gowa pada Badan Keluarga Berencana Dan Pemberdayaan Perempuan Kabupaten Gowa.

Selain mewawancarai, tim peneliti pun mengumpulkan berbagai dokumen sebagai informasi tambahan dalam penulisan ini. Dokumentasi adalah setiap bahan tertulis baik berupa karangan, memo, pengumuman, intruksi, majalah, buletin, pernyataan, aturan suatu lembaga masyarakat, dan berita yang disiarkan oleh media massa. Teknik analisis data yaitu tahap reduksi data, tahap penyajian data dan tahap penarikan kesimpulan. Keabsahan data pada penelitian itu yaitu menggunakan triangulasi sumber, triangulasi metode dan triangulasi sumber.

\section{HASIL PENELITIAN DAN PEMBAHASAN}

Eksistensi perempuan saat ini tidak dapat dipandang sebelah mata lagi, karena hadirnya perempuan di berbagai bidang mulai dari politik, ekonomi, sosial dan lain-lain menunjukkan bahwa perempuan berperan penting dalam kemajuan suatu negara. Namun dibalik semua itu, adanya diskriminasi yang dialami oleh perempuan serta stigma bahwa perempuan adalah subordinat dari lakilaki menjadi kendala bagi perempuan untuk mengaktualisasikan diri. Berbagai upaya telah dilakukan baik dari pihak pemerintah dan masyarakat sendiri sebagai bentuk keseriusan dalam memberdayakan perempuan. Tak terkecuali Peran Badan Keluarga Berencana dan Pemberdayaan Perempuan (BKBPP) di Kelurahan Kalegowa Kecamatan Somba Opu Kabupaten Gowa dalam memberdayakan kaum hawa di daerah tersebut tentunya melalui berbagai tahap dalam proses antara lain:

\section{1) Sosialisasi}

Sosialisasi adalah suatu kegiatan atau upaya yang dilakukan oleh seseorang atau beberapa orang (organisasi/perusahaan/lembaga

tertentu) memberitahukan suatu informasi untuk diketahui oleh umum atau kalangan tertentu. Sosialisasi tentang pemberdayaan perempuan 
merupakan kegiatan awal dari serangkaian proses pemberdayaan dan bagaimana peran Badan Keluarga Berencana dan Pemberdayaan Perempuan dalam menyampaikan apa saja yang terkait dalam proses pemberdayaan perempuan. Dalam wawancara para informan mengatakan :

"Sosialisasi tentang
pemberdayaan perempuan itu
sudah kita laksanakan di seluruh
Kecamatan di Kabupaten gowa
semenjak tahun 2008 s/d 2009,
mulai dari kecamatan dataran
tinggi hingga Kecamatan dataran
rendah" (wawancara, ID).

Pernyataan kepala bidang tersebut menunjukkan adanya sosialisasi tentang pemberdayaan perempuan telah dilaksanakan di daerah tersebut (Baca: Gowa) selama dua tahun berturut-turut diseluruh Kecamatan yang ada di Kabupaten Gowa.

\section{2) Pendampingan}

Pendampingan yaitu suatu proses mengorganisasikan kegiatan dimana didalamnya terdapat proses yang berupa penentuan tujuan, pembentukan lembaga/unit pembinaan, penyususunan rencana kerja kelompok usaha dan semua proses yang terkait dalam pemberdayaan kelompok usaha. Pendampingan ini perlu adanya untuk meningkatkan kapasitas para pelaku kelompok usaha, terutama dalam proses perencanaan dan penganggaran. Setidak nya dengan adanya pendampingan para pelaku kelompok usaha bisa menemukan potensi apa yang ada pada diri mereka, dan bisa membantu mereka menyelesaikan masalah sendiri.

Dalam pemberdayaan perempuan bentuk pendampingan yang dilakukan yaitu, persiapan pendampingan seperti mempersiapkan bahan pendukung, pelaksanaan pendampingan dilakukan dalam bentuk kunjungan, observasi dan diskusi, bentuk pendampingan yang terakhir adalah monitoring atau evaluasi seluruh kegiatan yang sudah dirancanakan dan dilaksanakan.

Hal tersebut senada dengan yang diutarakan oleh Ibu Kepala Bidang Pemberdayaan Perempuan, bahwa :

"sama halnya dengan sosialisasi dek, pendampingan juga kita sudah lakukan diseluruh Kecamatan yang ada di Kabupaten Gowa, pendampingan yang kami lakukan yaitu pendampingan kelompok usaha diseluruh kecamatan dikabupaten gowa, pada proses pendampingan kita pun juga bekerja sama dengan LSM dan Ibuibu PKK" (wawancara, ID)

Maksud dari pernyataan diatas yaitu pihak BKBPP sudah giat melakukan pendampingan bahkan sudah menyeluruh dan tetap dengan melakukan kerja sama dengan pihak LSM dan PKK.

\section{3) Pelatihan.}

Pelatihan perempuan merupakan suatu bentuk pemberian berbagai macam pemahaman tentang bagaimana seharusnya perempuan bila diperhadapkan dengan kondisi sosial yang ada baik dalam bentuk teori maupun praktik.

Guna meningkatkan ketrampilan dan menambah pendapatan keluarga di Kabupaten Gowa, Badan Pemberdayaan Perempuan dan keluarga berencana kabupaten Gowa mengadakan pelatihan berbagai macam kelompok usaha (Usaha peningkatan pendapatan keluarga sejahtera) yang ada di Kelurahan agar dapat dimanfaatkan menjadi sesuatu yang bernilai misalnya : Tas pesta, jajanan pasar dan penjahitan. Dalam pelatihan tersebut Badan KB dan PP yang bertindak sebagai pelatih dengan bantuan LSM dan Tim Penggerak PKK, adapun peserta dalam 
pelatihan tersebut yaitu perempuan yang tidak memiliki pekerjaan dan bersedia untuk belajar. Seperti yang diutarakan oleh Ibu Kepala bidang terkait pelatihan kelompok usaha yang mengemukakan bahwa :

"Pelatihan banyak kita sudah lakukan dan yang terkait kelompok usaha yaitu pelatihan bimbingan manajemen untuk kelompok usaha perempuan, serta pelatihan tentang desa prima, dimana kami ingin membentuk suatu desa yang didalamnya mayoritas perempuan yang memiliki kelompok usaha"(wawancara, ID)

Pernyataan diatas menunjukkan adanya pelatihan terhadap kelompok usaha secara teoritik telah dilaksanakan dengan materi bimbingan manajemen untuk kelompok usaha perempuan, pelatihan lain yang dilakukan yaitu pelatihan pembentukan desa prima, dimana desa prima yang dimaksudkan yaitu desa yang didalamnya terdapat kelompok usaha asuhan BKBPP.

Berjalannya suatu kegiatan itu diperlukan proses yang panjang dan proses itu diharapkan memberikan hasil yang optimal bagi pihak pelaksana kegiatan dan peserta dalam kegiatan tersebut. Dari bermacam-macam pendapat diatas dapat disimpulkan bahwa terlaksananya tahapan-tahapan pemberdayaan perempuan dikabupaten gowa itu tidak sepenuhnya dilakukan oleh BKBPP melainkan dengan bantuan dari pihak LSM dan Ibu-ibu PKK, jadi optimalnya kegiatan Pemberdayaan bukan hanya menjadi peran BKBPP melainkan banyak pihak yang terkait.

\section{E Faktor Pendukung Dan Penghambat Dalam Pemberdayaan Perempuan di Kelurahan Kalegowa, Kecamatan Sombaopu, Kabupaten Gowa.}

Faktor pendukung adalah segala sesuatu yang dapat menunjang terlaksananya

pemberdayaan perempuan sehingga dapat terlaksana dengan baik, baik itu materi maupun non materi. Berdasarkan hasil pengamatan yang dilakukan serta berdasarkan hasil wawancara dengan beberapa informan penelitian, ditemukan bahwa ada beberapa faktor yang menjadi pendukung dalam pelaksanaan Pemberdayaan Perempuan di Kelurahan Kalegowa, Kecamatan Sombo Opu, Kabupaten Gowa yaitu :

\section{a. Kebijakan}

Kebijakan merupakan serangkaian keputusan atau tindakan yang dibuat oleh Pemerintah Daerah dalam hal ini Kabupaten Gowa dengan tujuan dan arah kebaikan bagi masyarakat kabupaten Gowa. Kebijakan yang dikeluarkan oleh Pemerintah Daerah tidak lain untuk membantu masyarakat dalam menyelesaikan masalah tertentu. Kebijakan yang dikeluarkan selalu berpedoman pada perundangundangan. Hal ini dapat dilihat dari penuturan Kepala Bidang Pemberdayaan Perempuan, yang mengemukakan bahwa :

"pendukung terlaksananya
program pemberdayaan
perempuan itu ada kebijakan dari
pemda, dari daerah dan kebijakan
yang sangan mendukung yaitu
adalah pemberian bantuan untuk
kelompok-kelompok usaha, tahun
lalu ada dan untuk tahun ini ada"
(wawancara, ID)

Adanya pemberian bantuan dari Pemda Gowa merupakan salah satu faktor pendukung dalam pelaksanaan pemberdayaan bagi perempuan yang tergabung dalam kelompok usaha.

\section{b. Sarana dan Prasarana}

Sarana merupakan falilitas yang dipakai secara langsung atau yang 
utama. Sedangkan Prasarana merupakan fasilitas penunjang dari sarana. Sarana proses pemberdayaan yaitu khususnya di bidang Kelompok usaha penjahitan yaitu, mesin jahit, kain dan tempat usaha. Prasarananya yaitu alat transportasi untuk mencari bahan baku dalam proses penjahitan. Seperti yang dikemukakan oleh pelaku pemberdayaan kelompok usaha jajanan pasar, yang mengemukanan bahwa :

"begini kita ini kodong untuk usaha jajanan pasar yang menjadi sarana itu, alat produksi kue dan bahan bakunya kalau adami itu enak mi dirasa, kan ada juga sebagian teman yang baru mau mulai usaha jadi tidak adapi dasar untuk memulai kalau tidak disediakan bagaimana caranya dia mau belajar". (wawancara, MR)

Maksud dari pendapat diatas yaitu yang menjadi faktor pendukung adalah adanya alat produksi dan ketersediaannya bahan baku dalam proses pembuatan jajanan pasar sebagai faktor pendukung terlaksananya pembuatan jajanan pasar.

Pendapat diatas merupakan sarana dari proses pembuatan jajanan pasar, yang menjadi prasarana dari sarana tersebut akan dikemukakan dalam hasil wawancara informan sebagai berikut :

"kalau sudah adami semua bahan dasar dari proses pembuatan jajanan pasar kami selaku pihak pelaku pemberdayaan tinggal memikirkan bagaimana proses caranya supaya laku itu kue ta". (Ad : wawancara 20 maret 2014)

Maksud dari pendapat diatas yaitu yang menjadi prasarana dari sarana yang sudah dikemukakan oleh informan sebelumnya yaitu pelaku pembuatan jajanan pasar membutuhkan lokasi untuk memasarkan hasil produksi mereka dan juga sponsor atau orang atau media yang memperkenalkan hasil produksi mereka.

Selain dari faktor pendukung dalam proses pemberdayaan perempuan di bidang produkifitas, adanya faktor penghambat dimana segala sesuatu yang menjadi hambatan dalam proses pemberdayaan yang memungkinkan kegiatan tersebut tidak berjalan dengan baik atau mendapatkan hasil yang tidak optimal. Untuk lebih awal penulis akan memaparkan sedikit hasil wawancara dari informan yaitu kepala bidang BKBPP :

"sebenarnya hambatan tidak menjadi masalah karena semua sudah tersosialisasi dengan baik, buktinya kegiatan semua berjalan sampai sekarang". (Wawancara, ID)

Berdasarkan pernyataan tersebut diketahui bahwa hambatan bukanlah hal yang bisa manjadikan kegiatan pemberdayaan tidak optimal, BKBPP menganggap bahwa hambatan adalah sebuah masalah penting, dalam artian proses pemberdayaan yang dilakukan berjalan dengan baik.

Meski demikian hadirnya ranjau dalam kegiatan pemberdayaan tentunya menjadi indikator penting bagi BKBPP (Badan Keluarga Berencana dan Pemberdayaan Perempuan) yang perlu mereka (Baca: BKBPP) tinjau dalam memberdayakan perempuan. Adapun faktor penghambat dalam proses pemberdayaan perempuan oleh BKBPP di Kelurahan Kalegowa, Kecamatan Somba Opu, Kabupaten Gowa diantaranya yaitu :

a) Tingkat pendidikan

Tingkat pendidikan dapat mempengaruhi pengetahuan seseorang bagaimana seseorang mempunyai 
banyak pengetahuan tentang sesuatu dan lain hal apabila dia tidak banyak belajar, dan banyaknya pelajaran itu hanya bisa didapatkan di bangku pendidikan.

Pengetahuan yang dimaksudkan yaitu sejauh mana pengalaman masyarakat tentang perkembangan zaman yang menuntut atau mengharuskan perempuan untuk berubah. Perubahan yang dimaksud bagaimana perempuan bisa mengikuti perkembangan baik dalam bidang sosial, politik, ekonomi dan budaya selama masih dalam aturan agama yang dianutnya sehingga tidak ada lagi masyarakat yang beranggapan bahwa perempuan itu pantasnya di ranah domestik. Sesuai dari hasil penelitian di lokasi peneliti mendapatkan beberapa pendapat tentang adanya hambatan dalam proses pemberdayaan terkait dengan pengetahuan masyarakat. Terkait hal tersebut senada dengan penuturan salah satu informan kami yakni:

"salah satu faktor penghambat yaitu kurangnya pengetahuan masyarakat tentang pentingnya perempuan itu mempunyai potensi untuk membantu dirinya, apalagi kalau perempuan tidak mengenyam bangku sekolah, susah sekali itu mau diajak berpartisipasi" (wawancara, ID)

Penuturan diatas menyatakan bahwa banyak perempuan yang tidak menyadari potensi yang ada pada dirinya diakibatkan kurangnya pengetahuan yang dimilikinya. Terlebih lagi ditambah dengan tingkat pendidikan yang minim dan menjadikan pengalaman belajarnya kurang.

Hal ini dipertegas oleh salah satu kelompok usaha penjahitan dimana berpendapat tentang beberapa peserta pemberdayaan yang tingkat pendidikannya minim dan memberi efek tidak baik dalam proses praktek penjahitan :

"ada satu kelompok itu tidak efektip ki pelatihannya dalam hal ini praktek nya karena susah mau paham dengan apa yang diajarkan, na palabusu bahan ji juga, haruski sabar hadapi, kadang juga mereka jenuh karena lama mi belajar na belum juga paham". (wawancara, IF)

Penegasan tersebut mendukung adanya pemberdayaan kelompok usaha itu bukan saja membantu perempuan yang tidak bekerja untuk menemukan potensinya, tapi pemberdayaan disini bisa juga membantu perempuan yang bekerja bisa mengatur kondisi keuangannya dengan tidak lagi hanya mengandalkan orang lain untuk memenuhi kebutuhan keluarganya. Dengan adanya pemberdayaan para perempuan juga mempunyai bekal jikalau suatu saat nanti kehilangan pekerjaan utama atau bekal dalam menghadapi masa tuanya nanti. Kembali ketujuan awal pemberdayaan yaitu membantu perempuan menemukan potensi yang ada pada dirinya serta membantu perempuan menyelesaikan masalah yang ada pada dirinya.

b) Adat dan budaya

Adat dan budaya yang dimaksud yaitu kebiasaan-kebiasaan yang dilakukan perempuan atau masyarakat yang sudah mengakar atau berlangsung turun temurun dan dianggap melanggar norma bila kita tidak melakukannya dan dalam adat dan budaya juga masih banyak terdapat mitos atau kalimatkalimat yang berisis pesan atau amanah dari nenek moyang atau leluhur. Terkait hal tersebut ibu kepala bidang PP (BKBPP) Kabupaten Gowa yang memaparkan bahwa : 
"masih adanya internal kedalam masalah adat dan budaya, dimana masyarakat masih menganggap bahwa perempuan itu hanya pantas mengurus suami dan anak dirumah, untuk masalah keuangan suamilah yang bertanggung jawab padahal sekarang itu sudah beda lagi perempuan harus membantu suami" (wawancara, MA)

Pemikiran tersebut menunjukkan adanya doktrin bahwa sejak dahulu perempuan memang hanya pantas berada diranah domestik saja, zaman yang sekarang dianggap bukan sebuah norma yang baik bagi perempuan terkait dengan berbagai macam tuntutan pekerjaan, maka budaya tersebutlah yang berusaha dirubah dengan menanamkan pengertian bahwa pada zaman sekarang ini perempuan harus berjalan berdampingan dengan laki-laki tetapi perempuan harus tetap menjaga langkahnya agar tidak mendahului laki-laki.

\section{F. PENUTUP}

Berdasarkan hasil penelitian yang dilakukan terhadap penelitian guna mengungkap dan menjawab pertanyaan-pertanyaan penelitian yang berhubungan dengan Peran Badan Keluarga Berencana Dan Pemberdayaan Perempuan dalam Pemberdayaan Perempuan di Kelurahan Kalegowa, Kecamatan Somba Opu, Kabupaten Gowa maka dapat disimpulkan sebagai berikut:

1. Peran Badan Keluarga Berencana Dan Pemberdayaan Perempuan dalam Pemberdayaan Perempuan yaitu dengan melakukan sosialisasi tentang kelompok usaha kepada peserta pemberdayaan, pendampingan mulai dari tahap persiapan, pelaksanaan hingga evaluasi, dan yang terakhir yaitu pelatihan yang didalamnya berisi pelatihan pembuatan jajanan pasar, pelatihan tas pesta dan pelatihan penjahitan, dalam kegiatan tersebut yang berfungsi sebagai pelaksana yaitu Badan Keluarga Berencana Dan Pemberdayaan Perempuan yang dibantu oleh LSM (Lembaga Swadaya Masyarakat) serta tim penggerak PKK, sedangkan yang berfungsi sebagai peserta yaitu perempuan yang akan melakukan pemberdayaan. Dengan berjalannya peran tersebut perempuan sudah bisa malakukan akses, kontrol, manfaat dan partisipasi;

2. Faktor-faktor yang mendukung pelaksanaan peran tersebut yaitu Kebijakan yang berupa pemberian bantuan dana dari Pemerintah Daerah Kabupaten Gowa, sarana dan prasarana yang dibutuhkan oleh peserta pemberdayaan. Faktor-faktor yang menghambat yaitu, tingkat pendidikan dari peserta pemberdayaan dan adat atau budaya dilingkungan tempat tinggal atau keluarga peserta pemberdayaan.

Berdasarkan hasil interpretasi data dan kesimpulan diatas, maka penulis merekomendasikan saran dalam rangka terwujudnya peningkatan peran Badan Keluarga Berencana Dan Pemberdayaan Perempuan yakni dalam melakukan Pemberdayaan hendaknya melakukan pendekatan-pendekatan terlebih dahulu sebelum melakukan proses pemberdayaan agar terlebih dahulu mengetahui apa yang dibutuhkan perempuan dalam proses pemberdayaan.

\section{DAFTAR PUSTAKA}

Efendy, Mansyur H.A. 1994. Dimensidimensi Hak Asasi Manusia, Jakarta: Galia Indonesia. 
Miles, M.B and Huberman. M.A. 1984. Qualitative Data Analysis, London: Sage Publishing.

Moleong, Lexy J. 2012. Metode Penelitian Kualitatif, Bandung: Remaja Rosda Karya.

Muhadji, Noeng. 2002 Metodologi Penelitian Kualitatif. Bandung: Alfabeta

Nazir. Moh. 2003. Metode Penelitian, Jakarta: PT. Galia Indonesia.

Rahayu. I. T, Tristiadi Ardi. A. 2004. Observasi dan Wawancara. Malang: Bayu Media

Sonhaji, Ahmad. 1994. Penelitian Kualitatif dalam Bidang Ilmu-Ilmu Sosial dan Keagamaan, Malang: Kalisamada Press.

T.0. Ihromi, dkk. 2006. Penghapusan Diskriminasi Terhadap Wanita. Bandung: P.T Alumni.

\section{Dokumen :}

UUD Pasal 27 dan 28.

UU No. 10 Tahun 2008 Tentang Pemilihan Umum yang menjadi landasan hukum pemilu 2009.

UU No. 10 tahun 2008 pasal 33 memuat kuota $\quad 30 \%$ calon legeslasi perempuan.

UU No. 10 tahun 2008 pasal 55 ayat 2 mencantumkan system zipper atau disetiap tiga orang bakal calon terdapat sekurang-kurangnya satu orang perempuan.

Inpres No. 9 Tahun 2000 Tentang Pengarusutamaan Gender Dalam Pembangunan Nasional.

Keputusan Menteri Dalam Negeri No. 132 Tahun 2003 Tentang Pedoman Umum Pelaksanaan
Pengarusutamaan Gender Dalam Pembangunan Di Daerah.

Peraturan Daerah Kabupaten Gowa No. 45 Tahun 2008 Tentang tugas Pokok, Fungsi Dan Rincian Tugas Jabatan Struktural Pada Badan Keluarga Berencana Dan Pemberdayaan Perempuan Kabupaten Gowa. 